\title{
Os segredos da "barraca". \\ A representação da nação na literatura de guerra da \\ Guiné-Bissau
}

\author{
Moema Parente Augel ${ }^{*}$ \\ Universität Bielefeld (Alemanha)
}

$\mathrm{Na}$ Guiné-Bissau, numa exígua área de menos de 40 mil quilômetros quadrados, convive uma multiplicidade de grupos étnicos que se foram constituindo a partir de diferentes levas migratórias, ao longo dos séculos, como resultado da expansão de certos grupos e conseqüente deslocação de outros ${ }^{1}$. Conta-se cerca de uma vintena de etnias e igual número de línguas².

Até a queda do governo de João Bernardo "Nino" Vieira (19801999), podia-se falar de uma harmonia relativamente grande entre os diferentes grupos étnicos do país. A literatura testemunha essa harmonia através de versos de vários poetas. A chamada "geração da independência” marcou a cena cultural da primeira década da novel

\footnotetext{
* Moema Parente Augel é professora doutora aposentada de Língua Portuguesa e Cultura Brasileira na Universidade de Bielefeld (Alemanha). Este artigo foi apresentado pela primeira vez em Lusorama; Zeitschrift für Lusitanistik: Revista de Estudos sobre os Países de Língua Portuguesa, Frankfurt / Main: TFM, n. 67-68 (novembro de 2006), p. 84-114.

1. Sobre as regiões que hoje formam a Guiné-Bissau, cf. sobretudo Pélissier 1989 e Mendy 1994.

2 O território que hoje corresponde geopoliticamente à Guiné-Bissau foi outrora o refúgio de numerosos povos que se deslocaram devido às sucessivas invasões. Além disso, se se acrescentam as migrações internas e externas, a assimilação, a mestiçagem e destruições de várias naturezas, está-se diante de um mosaico complexo e multifacetado, incluindo um acúmulo de "poeiras étnicas" ou "micro-etnias" (Pélissier, 1989:19), muitas vezes com apenas algumas centenas de almas. Os grupos percentualmente mais numerosos são os Balanta (27\%), os Fula (22\%), os Mandinga (12\%), os Mandjaco (11\%) e os Papel ou Pepel (10\%).
} 
república com seus versos de repúdio ao colonialismo e glorificação da bem sucedida luta pela libertação nacional e de seus heróis, celebrando com fervor patriótico tanto a união entre os conterrâneos como a guineidade e a africanidade. A pátria nacional de todos nós, como cantou Pascoal D’Artagnan Aurigemma (1996:71)³, resumindo assim o sentimento geral. O que contava, no período da formação nacional, era a construção e a estabilização da nação guineense no seu conjunto, não sendo considerada como estorvo a diversidade entre as muitas etnias do país. Como versejou Tony Tcheka: Ninguém perguntou a ninguém / quem era / nem de onde vinha (Tcheka 1996:97) ${ }^{4}$.

A estabilidade do processo de entendimento entre as etnias depende fortemente do grau de estabilidade das relações políticas, econômicas e sociais. A consciência étnica se exacerba em situações de crise, de penúria, de luta pelo poder. A boa convivência entre as etnias pressupõe uma bem sucedida apropriação de espaços vitais individuais ou grupais.

Na Guiné-Bissau, a literatura que hoje se está fazendo no país pode incentivar um processo de tomada de consciência, por parte da população (penso na juventude nas escolas sobretudo, representantes do futuro do país), da história coletiva, do sentimento de pertença a uma "guineidade", sem descuidar das belezas e das singularidades da cultura de cada etnia, respeitando a identidade de cada uma, ressaltando a multiplicidade cultural e contribuindo para o entendimento entre os diferentes grupos e a superação de antigos conflitos étnicos.

\footnotetext{
${ }^{3}$ Pascoal D'Artagnan Aurigemma nasceu em Farim a 15 de março de 1938 e morreu em Bissau a 7 de dezembro de 1991 sem ver seus poemas editados. Alguns deles constam de coletâneas poéticas de autores guineenses, como por exemplo do Poilão (1973), da Antologia poética da Guiné-Bissau (1990) e de O eco do pranto (1992), ou encontram-se esparsos em jornais locais, como no Nô Pintcha e no Bolamense. O Instituto Nacional de Estudos e Pesquisa (INEP) editou sua obra completa, com o título Djarama e outros poemas (1996). Sobre o autor, cf. Augel, 1998a:195-216.

4 Tony Tcheka, pseudônimo pelo qual António Soares Lopes Júnior, nasceu em Bissau, é jornalista e poeta. É autor de Noites de insónia na terra adormecida (poemas, 1996). Sua produção jornalística, dispersa na imprensa nacional e estrangeira, sobretudo portuguesa, é abundante. Depois do conflito de 98/99, instalou-se em Lisboa, onde é redator chefe da revista África Lusófona. Sobre o autor, cf. Augel, 1998a:87-114.
} 


\section{A apropriação simbólica}

Sabe-se que os espaços vitais humanos são configurados pelas suas culturas específicas. Pode-se interpretar como pertencente à categoria da "apropriação simbólica" a internalização, por parte do indivíduo, do aparato simbólico dos elementos que constituem a marca cultural específica do espaço social do qual ele faz parte - tais como regras sociais, valores, códigos de comportamento e de ação e mesmo expectativas em relação aos papéis sociais a desempenhar.

O termo "apropriação" é usado em múltiplos contextos. Trata-se de uma interação ativa e criativa entre a pessoa ou um grupo de pessoas e seu ambiente material ou social. Uma apropriação simbólica faz referência ao ato de tornar seu, da pessoa ou do indivíduo, o que também é do domínio de outros indivíduos, de muitos, de todos, tanto de uma cidade, de uma nação ou de um estado. Falar de uma casa, um bairro, uma cidade, um país, da pátria e da língua "materna", de um governo ou de um povo como o "meu" ou a "minha" implica em pertença e em identificação positiva, muitas vezes em relação a algo que, como um bem público, é do domínio de todos, não excludente e não sujeito a concorrência, como por exemplo a língua, a maneira de se vestir, a memória coletiva e signos e símbolos culturais de todo tipo.

As idéias desenvolvidas por Homi Bhabha, Benedict Anderson, Stuart Hall, tão caras aos Estudos Culturais, poderiam igualmente encontrar aqui aplicação. No momento, para a finalidade deste artigo, basta reter que, sendo muitos e muito diversos os conceitos sobre a nação, uma noção básica é aquela que define a nação como uma entidade primordial que se impõe aos indivíduos na medida em que possuem em comum alguns elementos como o território, a língua, a cultura sobretudo, e também a raça, a religião, traços que a fazem existir objetivamente, como "feito social", independentemente dos indivíduos e do que pensem os sujeitos. Um conjunto de significados converge num sistema de representação cultural a partir do qual se 
sedimentam as identidades culturais (Hall 2000:49). Anderson (1991:57) cunhou a expressão que se consagrou, definindo provocativamente a nação como uma comunidade política imaginada, limitada e soberana. Essa comunidade, que pressupõe uma nova visão compartilhada, tende a ultrapassar as raias étnicas. No presente artigo, interessa-me considerar em primeiro plano as idéias em torno da etnicidade, sobretudo da sua construção simbólica, por me parecer mais adequada à tônica dos poemas a serem aqui apresentados.

$\mathrm{Na}$ antropologia, o termo "grupo étnico" designa em geral uma comunidade que se perpetua biologicamente, que compartilha valores culturais fundamentais e cujos membros se identificam e são identificados por outros como constituindo uma categoria diferenciável de outras categorias do mesmo tipo ${ }^{5}$. Grupos sociais são qualificados como grupos étnicos quando, além do forte sentimento de pertença que os une numa identidade coletiva, possuem certas características em comum, como a língua, a história, a religião, a mesma cultura, as mesmas tradições. Os grupos étnicos devem ser identificados sobretudo pelos seus suportes culturais. A identidade étnica é associada a um conjunto cultural específico de padrões valorativos.

A obra de Fredrik Barth, com sua teoria sobre os grupos étnicos e suas fronteiras (ethnic boundaries) é especialmente relevante para o alargamento desse conceito. O termo fronteira é por ele empregado tomando em consideração critérios de pertença e de exclusão, marcando a distância que se estabelece entre o "nós" e o "eles". Entendo, portanto, a etnicidade como uma categoria que põe em relevo tanto o sentimento de pertença como o de alteridade. O conceito de etnicidade interessa à minha análise no momento em que pretendo ressaltar a ancoragem social do grupo que sustenta certos traços culturais relevantes para a tomada de consciência identitária, refletida

5 Cf. Fredrik Barth, "Grupos étnicos e suas fronteiras", in Poutignat / Streiff-Fenart, 1998:189-190. Barth é considerado um autor básico para os modernos estudos relativos à etnicidade. Seu livro mais conhecido, uma obra coletiva por ele organizada, Ethnic groups and boundaries, já data de 1969. 
na Guiné-Bissau sobretudo nas obras literárias nascidas com o conflito fratricida de 1998/99.

\section{A construção social de etnia}

É a história comum que os habitantes de um território vivenciam e o seu passado compartilhado que nacionalizam um espaço geográfico e preenchem o território pátrio de conteúdo mítico e de sentimentos sagrados. É oportuno considerar-se aqui uma outra conotação, mais abrangente: a de uma "construção social de etnia", uma vez que tal fenômeno ocorre em situações de crise ou conflito e onde forçosamente se estabelece um binarismo polarizante entre o "próprio", o "nós", de um lado e, do lado oposto, o "alheio", o "estranho", o "outro". Ambas as frentes carregam-se de um sistema específico de significados e de símbolos, delimitando claramente os espaços sociais.. Foi o que se deu na Guiné-Bissau e a literatura produzida naquele momento espelha essa extrema tesão6.

$\mathrm{Na}$ Guiné-Bissau, enquanto guineenses, senegaleses e outros estrangeiros sempre viveram em harmonia em tempo de paz, as diferenças e a antipatia latentes em relação sobretudo aos comerciantes do Senegal, país imediatamente vizinho e com o qual existe há mais de um século uma grande tensão devido à disputa pela posse da estreita faixa de Casamansa ${ }^{7}$, foram exacerbadas de forma violenta por ocasião do conflito armado de 1998/99. A rejeição aos senegaleses foi completa, subindo à tona os ressentimentos provocados pela concorrência, uma

\footnotetext{
${ }^{6}$ Sobre o conflito que abalou a Guiné-Bissau de junho de 1998 a maio de 1999, cf. o número especial da revista Soronda, com o título 7 de Junho. Soronda. Revista de Estudos Guineenses. Bissau: INEP, Nova Série, $\mathrm{n}^{\circ}$ 2, dezembro 2000. Cf. ainda Augel, 1998b, Guiné-Bissau ka pudi kaba (a situação político-social que precedeu ao conflito e as primeiras semanas da guerra). O artigo está em português, accessivel na internet: hppt:/www.uni-bielefeld.de/sdrc/homesdrc.

7 Casamansa é uma estreita faixa de terra ao sul do Senegal, na fronteira com a Guiné-Bissau, de antiga colonização portuguesa, onde atua um movimento independentista que provoca há décadas grandes problemas entre os dois países. Ali se fala um crioulo muito semelhante ao crioulo guineense e há profundos laços de ligação, inclusive familiares, entre os habitantes da Casamansa e os das terras guineenses vizinhas.
} 
vez que os comerciantes senegaleses sempre foram muito bem sucedidos na Guiné-Bissau e ocupam uma grande percentagem do mercado local.

A presença dos soldados senegaleses, acorridos a pedido do próprio chefe de estado guineense, presidente "Nino” Vieira, para ajudálo a abafar a "revolta da caserna" de junho de 1998 mudou o caráter daquela guerra fratricida e os sentimentos do povo adquiriram uma nova qualidade. O território nacional estava de repente ameaçado. Mais do que as fronteiras geográficas, era a fronteira social, e mesmo emocional, que estava em perigo. O território passou a adquirir uma transcendência, passou a ser um atributo cultural e social ao qual foi dada uma prioridade e uma urgência, definindo-se por ele, através dele, a identidade nacional. Estava sendo ultrajado o espaço da pertença, componente indispensável de toda soberania política, ancoragem simbólica e de fato identificatória, anulando as diferenças, fazendo surgir uma força catalizadora, amalgamando o país. A área geográfica, o território passou metonimicamente a simbolizar a nação, pois, como disse Anderson, o território é o receptáculo do passado e do presente (1989:24).

O papel da etnicidade (o sentimento de pertença, de um "nós”) e o da alteridade (a percepção do "outro") nas obras literárias dos autores guineenses se fez notar de forma aguda no momento extremo desse conflito armado de 1998/99. O "outro" passou a ser exclusivamente o invasor, esquecendo-se qualquer tipo de rivalidade ou de concorrência entre as etnias do país. É o tema de que vou tratar a seguir, procurando detectar nos poemas inéditos de Huco Monteiro e de Respício Nuno, escritos durante esse conflito militar, as relações emocionais e cognitivas do indivíduo com seu espaço vital, isto é, com seu ambiente social e material, no qual diariamente sua vida se desenrola. A ligação sentimental e afetiva ao chão pátrio, a identidade a ele relacionada, diante do perigo provocado pela presença dos soldados estrangeiros, tornaram-se extremamente conscientes e dolorosas, provocando versos lancinantes e acalorados, de grande qualidade estética. 


\section{"Sinais de Paz" e o segredo da barraca}

Huco Monteiro ${ }^{8}$, durante o conflito, pela via eletrônica, enviou a amigos textos de angústia e de pungente beleza mas que até agora não foram publicados. O poema "Sinais de Paz", ainda inédito, oferece ocasião para refletir sobre o drama do ser desterritorializado devido a percalços externos à sua vontade. O poeta vê territórios existenciais originais, conforme Felix Guattari (1994) - corpo, espaço doméstico, clã, culto - desintegrarem-se em um mundo de representações precárias e em transformação. O seu espaço vital (seu território, sua nação) estava ameaçada e o poeta reage com toda a intensidade da sua emoção face ao perigo vindo de fora. Embora seja fartamente sabido que sempre, em todas as etapas da história, o arcabouço formador das nações é constituído pela brutalidade das conquistas, ou pelo traçado arbitrário das fronteiras ou por outras circunstâncias quase sempre fortuitas e violentas, esse espaço geopolítico que constitui a Guiné-Bissau adquiriu força congregadora e despertou novo interesse de pertença, confirmando o que Ernest Renan já dizia, ser a nação uma "família espiritual” (Renan, 1947:903).

Importante para esta análise é se ter em conta a qualidade da percepção subjetiva da realidade em relação ao estrangeiro, leia-se, no caso, aqui, sobretudo os senegaleses, por parte da população guineense, durante o conflito. A convivência pacífica e amistosa entre as gentes do lugar e esses estrangeiros mudou radicalmente, passando eles a serem vistos como inimigos, invasores, indesejáveis e ameaçadores. Preconceitos e estereótipos mais latentes que expressos, com os quais os forasteiros eram desqualificados de uma forma branda ou mesmo divertida, foram exacerbados, transformaram-se bem

8 Huco Monteiro (João José Silva Monteiro), nascido a 19 de fevereiro de 1959, até agora publicou apenas em antologias. Formado em Estudos Sociais em Dijon e com pós-graduação em Paris, foi titular de vários ministérios de seu país e hoje é o vicereitor da recentemente fundada Universidade Colinas de Boé (Bissau). Como poeta, escreve somente em crioulo e está presente com dez poemas na coletânea Kebur (1996). 
depressa em estigmas. Ao mesmo tempo, o que era familiar e tradicional, assim como os costumes locais, foram supervalorizados e carregados de conotações positivas e laudatórias.

Em "Sinais de Paz", poema de 42 versos, distribuídos em 9 estrofes de extensão variada, Huco Monteiro desenvolve dois pensamentos centrais: o horror ao inimigo e o amor pela pátria. O sujeito da enunciação parte primeiramente da constatação da desorganização material e moral causada pela luta armada e pela presença de soldados vindos de outros países, indesejados em todos os sentidos, desconhecedores das tradições locais.

O poeta, portador da experiência coletiva, vai pautar a sua escolha lexical na busca de símbolos referentes a esse rico acervo. Muitos dos seus tropos tanto são baseados em imagens tiradas dos rituais das etnias que praticam o culto das religiões tradicionais, como se reportam a costumes das etnias islamizadas. A preservação de uma memória cultural comum é sentida pelo eu poético como um possível baluarte contra a perda da auto-estima e reconhece-se no texto o claro intento de pôr em relevo a unidade dentro da diversidade, numa tentativa de resgatar os valores identitários desmantelados. É patente o desejo de valorizar os elementos étnicos de diferentes origens, numa apropriação símbólica da identidade coletiva, para com isso contribuir para o entendimento interétnico e fortalecer a unidade nacional.

No momento em que as fronteiras do país foram violadas e forças estrangeiras acorreram ao chamado do próprio Presidente da República que viu receou (com razão) não contar com o apoio nem da maior parte dos militares nem da população, o povo guineense, ultrajado, sentiu sua soberania posta em perigo. A ocupação da capital por tropas estrangeiras despertou no poeta uma especial indignação e os ocupantes são evocados ora com ironia, ora com violência. Rejeitando energicamente a ingerência de estranhos, o poema defende a integridade do território guineense, fazendo uso de uma linguagem original e criativa, toda calcada na cultura multifacetada do povo guineense. 
O sentimento de pertença ao território-nação recrudesceu, as diferenças grupais internas ficaram relegadas a um plano secundário e verificou-se a tomada de consciência dos antagonismos em relação ao estrangeiro invasor, hipostasiadas naquele momento. A lembrança dos onze anos das lutas libertárias volveu à tona, empalidecendo todo um passado traumatizante de rebeldias e submissões que na verdade desenharam e determinaram o traçado multiétnico da atual GuinéBissau. É a lembrança comum e gloriosa da vitória contra o colonialismo que constitui o fundamento simbólico da história do povo guineense, não devendo ser confundido com a história real das populações. "A memória fundadora da unidade nacional", afirmam Poutignat e Streiff-Fenart, "é, ao mesmo tempo e necessariamente, esquecimento das condições de produção desta unidade: a violência e o arbítrio originais e a multiplicidade das origens étnicas" (Poutignat e Streiff-Fenart, 1998:34-36). Essa dialética, englobando a memória e o esquecimento, continua atual e na base de muitas modernas configurações do significado e da idéia da nação ${ }^{9}$.

Referindo-se ao seu país, naquele momento ameaçado, Huco Monteiro apropria-se dos símbolos sagrados da nacionalidade, usando enunciados explícitos como "pátria”, "república”, "nossa terra”, "nosso chão" (no tchon), mas também metonímias e sinédoques tais como os topônimos Bissau, Brá, Bissalanka, P’Nghana, barraca (o local reservado e secreto do fanado e que foram funcionalizados representando ora ameaça e perigo, ora orgulho, resistência e amor).

Vale a pena conhecer o poema inteiro. A tradução literal que fiz para o português não tem intenções literárias e obedece apenas a finalidade de facilitar a compreensão do poema ${ }^{10}$. Numerei as estrofes e os versos para facilitar as referências durante a análise do texto:

\footnotetext{
9 Tais idéias encontram-se primeiramente na obra de Ernest Renan, 1947:891-892.

10 Fui obrigada a desenvolver às vezes certas idéias que, na língua guineense, são expressas de modo muito conciso. Coloco entre colchetes minhas interferências e entre parênteses as alternativas para a tradução. A pontuação, como a numeração dos versos e das estrofes, são minhas. Mas respeitei a grafia utilizada pelo autor. Agradeço
} 
Sinais de Paz

I 1 Alinu-li na mentu ntidu ku balas surua

2 Bandé trás, Kiliquir dianti

3 Nô firma suma nô matchundadi

$4 \quad$ Na defesa di sigridu di baraka

II. 5 Ali élis li é na njata ka na retourner

6

È ka kunsi nin Kankuran nin Ussai Plek

$7 \quad$ Kada kim kada Ndjol kada Ndjai arnegu di élis

$8 \quad$ Ma é ka tissi nin fuka nin bissap

$9 \quad$ Arma na kosta pa montia Republika rebelde

III.10 Ala é na bai fidjus di Ndjai Té kuma Ndjai Djú
Sinais de Paz

Estamos a ser obrigados [a jogar o jogo] mentu ntidu [com balas dos suruás

Bandim [ficou] para trás, Calequir [está] adiante

Nós ficamos de pé, assumindo nossa coragem

Na defesa do segredo da nossa barraca.

Aí estão eles e afirmam com arrogância que não vão [regressar [para casa, para o país deles].

Eles não conhecem nem o Kankuran nem o Ussai Plek (eles não conhecem a ameaça que paira sobre eles).

[Há aqui] tantos Ndjol, tantos Ndjai, arrenego todos eles

Pois eles não trouxeram roupas para comerciarem nem bissap para [venderem]

Trouxeram, sim, armas nas costas para caçar a República rebelde.

Lá vão eles, os filhos de Ndjai Té e até mesmo os Ndjai Djú

a Huco Monteiro as preciosas explicações que me deu, sem as quais não me teria sido possivel a total compreensão do texto. 
Lutu di Brá i ka tchiga fidi lifanti IV. 14

Binhalé un djamba na polon bu fogantal na Puntu Sibi

16

Montiaduris nhominca salta na Djiba i

djunki na Nghala

V. 17 Alinu li ku elis suma tap ku bangadje

18

Ronku i ku elis

Ma badju di Brá i djambadon

19

20 Guer lambés na toka sikó djamba na badja kafé kinti

VI.21 Alinu li na kassabi di P'Nghana

22 Kada familia i un stera di tchur
Cordas grossas na cintura,

Canela seca, cabelo como bosta de cabra.

Maldição aos Djop [que querem capturar, que se atreverem a ir ] a Bissalanka.

A batalha de Brá não vai levar à vitória.

[A resina do] binhalé prendeu o pardal no poilão e tu o afogaste [na ponte Sibe,

Os caçadores senegaleses desembarcaram em Geba e se instalaram [até em Nghala

Estamos aqui com eles, (inseparáveis) como a rolha e o gargalo da garrafa.

Eles andam sempre bem aprumados, Mas em Brá dança-se é o djambadon.

Os veteranos na guerra vão tocar sikó e os djambas [em pânico] [vão dançar muito depressa.

Estamos aqui na tristeza [ por causa de] de P’Nghana.

Cada família é uma esteira de choro (Há um morto em cada família)

Cada surua é um fantasma espalhando a dor na Pátria. 
VII. Ali é nega far kussa di bai kuma Bissau

24 mela tchut

25

26

Ali élis li é na sussa lensolis di Pátria

27

È na sibi riba ku bás

28

Suma djintis ku bin nan ten Tchon

29

Alinu li ku returnez na totis

30

Albés ku fomi albés ku sedi

31

Pontada kumpridu

32

Ma é nega bai

VIII.

È na buska Repúblika pa montia

35 Alinu li nô firma tchan

36
Aqui eles recusam-se a ir embora pois Bissau é doce como o mel.

Armas na ilharga, óculos escuros como os de Bubu Na Tchut,

Eles estão aqui a macular os lençóis da Pátria,

Vagueiam [pela cidade] para cima e para baixo

Como conquistadores que vieram apropriar-se do nosso chão.

Aqui estamos com os "retournez" nas costas,

Os senegaleses estão famintos, os senegaleses estão sedentos,

Suas costelas estão longas,[ à mostra],

Mas mesmo assim se recusam a ir embora.

Aqui estão eles, confundindo M'Pandja com Psak

(desconhecendo a topografia da cidade).

Eles estão querendo capturar a República.

Aqui estamos nós firmes, com o pênis erecto (como verdadeiros machos),

Como [o tronco de] um pau de sangue. 
X. 37 Certeza na kabeça

38

39

40

41

42
Amanhã suma farol dianti

Esperança na pitu

Nô ndianta ku nô Terra

Pabia di amanhã

Djitu ten na glória di Brá!
A certeza nas nossas mentes,

O amanhã como um farol à [nossa] frente,

A esperança no coração,

Avançamos sempre adiante com a nossa terra,

[E] por causa do amanhã

Venceremos na glória de Brá!

Parece-me oportuno transmitir certos esclarecimentos, pois o acúmulo de metáforas e de símbolos tão específicos da multiculturalidade guineense pode acarretar dificuldades para a compreensão e apreciação do texto. Vou proceder tratando estrofe por estrofe:

As metáforas empregadas para manifestar o desagrado pela situação em que o povo se encontra são carregadas de ressentimento. Os estrangeiros, aqueles que estão fora de nós ${ }^{11}$, o eu poético os arrenega a todos, amaldiçoando-os ou ridicularizando-os. Já na primeira estrofe, o poeta revela a força da engrenagem da violência. Os senegaleses (aqui denominados surua) obrigam os guineenses a jogarem segundo suas regras, a regra do medo e da brutalidade. No primeiro verso, o poeta se refere a um jogo tradicional, o mentu ntidu, da etnia mandinga, mas também usual na cultura crioula, onde ganha aquele que dá o último toque.

Esses estrangeiros não estão ali para vender seus produtos, roupas ou alimentos, como antigamente, mas trouxeram armas mortíferas e destruição, sendo desqualificados com violentos pejorativos. Esses invasores não praticam as tradições nem conhecem

11 Em verdade, a expressão "fora de nós" refere-se, na língua guineense, às almas do outro mundo, o que torna o eufemismo dirigido aos senegaleses ainda mais negativo. 
os costumes locais nem os espíritos protetores nem os rituais, não conhecem os bairros da capital nem muitos locais do país, nem tampouco os jogos nem as brincadeiras, nem as danças típicas. O poeta refere-se ao Bandim (v. 2), o enorme mercado popular de Bissau, centro nevrálgico do comércio informal, onde se pode comprar (e vender) de tudo, desde produtos alimentícios a tecidos, roupa pronta, ferragens, peças para carros ou computadores. Calequir é um outro bairro de Bissau. A barraca (baraka), aqui (v.4), é a barraca do fanado, isto é, o local onde se desenrola o ritual de iniciação. O fanado é secreto e muito complexo, com muitas etapas e ritos, próprio de muitas etnias do país, diferindo sobretudo segundo a crença religiosa. Metonímia para a Guiné-Bissau, a imagem sugere que não se admite a ingerência de estranhos ${ }^{12}$.

Na segunda estrofe, as referências culturais locais não se limitam a uma única etnia. Entre os Mandinga, etnia islâmica, o Kankuran (v.6) é o espírito guardião do fanado. O Ussai Plek é a divindade (o iran) do fanado dos Pepel, Mandjaco e Mancanha, a divindade da mata sagrada onde se desenrola grande parte dos rituais de iniciação e não só. Ambos são espíritos muito poderosos, representados com roupas e máscaras medonhas, e protegem o grupo enquanto está na reclusão, mas também, conforme a situação, são agentes de castigo e repressão. Os

12 O fanado é uma importante etapa da vida comunitária, tempo de iniciação quando se preparam os jovens de ambos os sexos para a vida adulta, para a responsabilidade social, instruindo-os inclusive para o contacto com os antepassados, ensinando-lhes as tradições culturais do próprio povo (Scantamburlo, 2002:207). O termo vem do verbo fana, que remete para uma das práticas mais secretas e decisivas da preparação para a vida adulta e significa "ter cortada a membrana do prepúcio do pênis (circuncisão masculina) ou ter cortados os lábios da vulva ou o clítoris (excisão feminina)". Embora algumas etnias pratiquem a excisão enquanto a menina ainda é pequena, trata-se de uma prática ainda muito divulgada e freqüente, embora tabuizada, difícil de ser erradicada apesar dos muitos protestos de certas camadas da sociedade que tentam pelo menos que a operação se faça obedecendo a certas regras de assepcia. O fanado, entretanto, é mais do que apenas esse momento, podendo alongar-se por meses; compreende diversos rituais e cerimônias, algumas secretas, outras nas quais toda a comunidade participa, como no momento da saída da "barraca sagrada". Se em geral esse rito de iniciação ocorre na juventude, em algumas etnias dá-se o caso de esse momento acontecer apenas bem mais tarde; fala-se de "jovens sociais", pois pode suceder que o indivíduo só vá para o fanado aos quarenta anos, e só então passa a ser considerado "adulto social" (informação concedida por Teresa Montenegro, a quem agradeço). 
antropônimos Ndjol e Ndjai (v.7) apontam para famílias no Senegal. Fuka (v. 8) é um termo da língua guineense, significa roupa usada para vender, um dos comércios mais lucrativos dos senegaleses na GuinéBissau; o bissap é a floração de uma leguminosa comestivel (hibiscus sabdarifa); de cor vermelha e sabor muito ácido, de muito uso entre os senegaleses mas também entre os guineenses, que a chamam em crioulo de ondjo, e dela fazem uma infusão de grande valor nutritivo, rico em ferro e em vitamina $\mathrm{C}$, tomada quente ou sobretudo como refresco.

Também do ponto de vista da linguagem, Huco Monteiro lança mão de uma grande mistura: o verbo ndjata (v.5) é um termo da língua guineense e significa afirmar com orgulho ou arrogância; tratando-se do hiperônimo de jactar-se e de enjeitar, segundo Scantamburlo (2002). No mesmo verso, o poeta utiliza o verbo francês, retourner (voltar, retornar), língua oficial do Senegal, acentuando ainda mais o caráter estrangeiro da invasão. O termo, preferido na forma do imperativo retournez, foi popularizado durante a guerra para designar o militar estrangeiro, nos check points instalados nas ruas da capital, pois era uma ordem freqüentemente ouvida pelo povo, instado a parar e não prosseguir nem ousar continuar o caminho por onde ia.

A ocupação da capital por tropas estrangeiras despertou no poeta uma especial indignação e os ocupantes são evocados ora com ironia, ora com violência. Rejeitando energicamente a ingerência de estranhos, o poema defende a integridade do território guineense, fazendo uso de uma linguagem original e criativa, toda calcada na cultura multifacetada do povo guineense.

$\mathrm{Na}$ terceira estrofe, além da referência aos Ndjai, sobrenome senegalês, o poeta acrescenta que ao lado deles estão os Ndjai-Djú, denominativo aqui dos guineenses desnaturados que atiram contra seus irmãos, fazendo a guerra junto aos senegaleses, traindo os interesses da nação (v.10). No verso 11, há referência às cordas grossas que os soldados senegaleses usam enroladas à cintura e que servem para amarrar o inimigo capturado; entretanto, permitindo-se mais um 
desvio de significação, o poeta emprega para isso o termo em crioulo para designar a corda com a qual as balsas não motorizadas são puxadas para a terra. O verso 12 mostra o desprezo pelo inimigo, ridicularizando sua aparência física, ojeriza reforçada no verso seguinte. Djop (v.13) é também um sobrenome senegalês. Bissalanka é uma região logo depois do aereoporto, bem próxima a Bissau, ponto muito visado pelos invasores naquele conflito.

No primeiro verso da quarta estrofe (v.14), há de novo a referência a um costume das etnias "animistas": o fidi lifanti é uma competição numa das fases finais do fanado. Trata-se de um evento realizado na véspera da saída da reclusão, um tipo de maratona, na qual aquele que, correndo, alcançar e bater primeiro no tambor é o vencedor. $\mathrm{O}$ enunciado tem, na verdade, segundo informação do próprio autor, dois sentidos: ou significa "bater no tambor", ou pode referir a uma competição que se realiza nessa mesma ocasião e que consiste em o jovem mostrar ter a força e a coragem de segurar um javali e lançá-lo contra uma grande árvore. Essas competições provam a destreza e o bom preparo físico dentre os melhores daqueles que se submeteram ao fanado. Vencendo as provas, estão de fato aptos a enfrentar a vida adulta, a nova vida que começa depois dessa fase preparatória. O poeta quer expressar que os invasores que lutam para conquistar Brá, local divisor das fronteiras entre os senegaleses e os rebeldes guineenses, não serão os primeiros a alcançarem o tambor ritual, ou a vencer a maratona, eles não vão, portanto, chegar à vitória final. O verso 15 expressa que guerrear contra os senegaleses é tão fácil como apanhar passarinhos e depois jogá-los na água para afogá-los. O djamba é um passarinho pequeno de plumagem escura, tipo pardal; e o autor está aqui fazendo um trocadilho com o termo djambar, mais uma das muitas expressões para designar o senegalês. O djamba (ou o inimigo senegalês) foi capturado, ficou preso, grudado no poilão (grande árvore local, tida como sagrada), como se fosse o passarinho djamba, e para isso utilizou-se um método tradicional, passando-se uma resina chamada binhalé nos galhos das árvores; as aves ficam grudadas nessa 
resina e podem assim ser facilmente capturadas. Os guineenses, diz a voz poética, derrotaram sem dificuldades os senegaleses na ponte Sibi, local perto de Bissau, onde houve um grande número de mortos e que assinala uma das fronteiras entre as duas forças antagônicas. O verso 16 refere-se aos Nhominka, indicativo do povo Serere, do Senegal, um povo de pescadores, etnia que também se encontra na Guiné-Bissau. Esses "caçadores senegaleses" chegaram ao rio Geba (Djiba) e mesmo até a aldeia balanta de nome Nghala, isto é, adentraram-se pelo interior do país, sinal de grande ameaça e perigo.

$\mathrm{Na}$ quinta estrofe, o poeta expressa com desgosto o quanto o convívio com o inimigo é desagradável. Eles não querem sair, estão agarrados aos guineenses como se estivessem colados um ao outro, como a rolha está presa ao gargalo da garrafa (tap ku bangadje, v.17). Os senegaleses podem mostrar-se superiores, "roncarem" (v.18), que é o termo na língua guineense para vangloriar-se ou para apresentar-se bem vestido. Podem estar bem bonitos e bem trajados para o baile (isto é, muito bem armados), mas o baile de Brá13, isto é, a guerra, embora pareça fácil (festiva), não o é; pois eles não sabem dançar a dança ritual e por isso mesmo vão de lá sair fugidos, derrotados, portanto (v.19). O último verso da estrofe é também cheio de imagens diretamente ligadas à história das lutas gloriosas da libertação (guer, a "guerra"). A lembrança das vitórias obtidas naquela ocasião é acentuada pela referência aos lambé ${ }^{14}$, aqueles que já tiveram a experiência de luta, o batismo do fogo. Esse substantivo é aqui utilizado transgressoramente como adjetivo (guer lambé). Os veteranos da guerra da libertação, os assim chamados antigos combatentes pela liberdade da pátria, sabem lutar e os senegaleses fogem em pânico. A imagem utilizada para a idéia de guerrear é, entretanto, de novo ligada à cultura local: os antigos combatentes eram animados com canções marciais acompanhadas do sikó, instrumento de percussão (espécie de pandeiro), típico da região.

\footnotetext{
13 Atualmente, a cada aniversário do início do conflito, são depositadas coroas de flores ao pé do poilão de Brá.

14 Os lambés são aqueles que já participaram das cerimônias de iniciação sendo, portanto, mais experientes.
} 
Com a força encantatória de seus versos, o poeta ressalta que esses valentes guerreiros que já demonstraram seu valor, vão agora vencer os inimigos com o som da sua música e fazê-los fugirem de medo ("dançar muito depressa"). A expressão corrente da língua guineense para "muito depressa" é também uma metáfora pitoresca: kafe kinti (v.20).

Firmar a fraternidade e pôr em relevo a unidade da nação guineense são as duas aspirações máximas do poeta. Nesse sentido, Huco Monteiro apela para as glórias passadas, para o papel heróico dos antigos combatentes da liberdade da pátria, pois a guerra anticolonial continua a ser o orgulho nacional. A evocação histórica é seguida pela referência a heróis da guerra atual e às vitórias alcançadas. Com isso, o autor faz intencionalmente a ligação entre dois momentos importantes para a história pátria, a guerra da independência e a guerra que a Guiné-Bissau estava vivendo naquele momento. Essa justaposição, essa interpenetração da atualidade no pano de fundo do passado é de suma importância. Foi a guerra anticolonial do país que fez surgir a nação guineense; foi a guerra contra os estrangeiros que uniu a nação contra o novo inimigo. Foi a guerra da independência que fez surgir os celebrados heróis da liberdade da pátria; os heróis atuais estão lutando com a mesma bravura. Foi a guerra passada que unificou a diversidade das etnias e as fez superar os antagonismos existentes; é a guerra contra o inimigo externo atual que fez o povo reunir todas as forças com a mesma finalidade. E assim como a guerra da independência foi vencida gloriosamente, o mesmo ocorrerá naquela que se estava desenrolando no momento da elaboração do poema.

A sexta estrofe expressa a profunda tristeza e o grande desgosto causados pela guerra. P'Nghana designa uma região sagrada da etnia pepel, ao norte de Bissau, e aqui o termo é tomado metonimicamente para indicar a zona do conflito (v.21). A esteira de choro (v.22) é estendida nas cerimônias fúnebres de muitas etnias, quando as mulheres se sentam numa esteira para carpir a dor. Há mortos em todas as famílias, os invasores, como espíritos maus, espalham o sofrimento por toda a pátria (v.23). 
Novamente imagens locais colorem o poema na sétima estrofe. Para expressar como os estrangeiros estão gostando de estarem aquartelados no país, o poeta revela que "Bissau é tão doce como o mel”, reforçando a afirmação com o advérbio crioulo de intensidade tchut (v 24). No verso seguinte, é feita uma referência a uma vivência histórica daquele momento: [Américo] Bubu Na Tchut ${ }^{15}$ é o nome de um dos comandantes da Junta Militar que se levantou contra o então presidente "Nino" Vieira; era um militar muito temido e famoso durante a guerra que se estava desenrolando (1998/99), apresentando-se sempre de óculos escuros (lunetas, na língua guineense).

Um efeito colateral de toda ocupação militar é o relacionamento entre os soldados e as mulheres da região. A violência dos estrangeiros se estende às mulheres guineenses, violadas e vilipendiadas. Mas também há relacionamentos não conflituosos entre os dois sexos, sugerindo uma colaboração com o inimigo, e ambos os casos constituem uma vergonha que "suja", "macula" toda a pátria (v.26). Aqui nesta estrofe aparece de novo a expressão jocosa "retournez" (v.29) para designar os senegaleses que, embora passando necessidades, estando magros, com fome e com sede (v.30, 31), persistem em continuar no país como invasores.

A oitava estrofe mostra como o inimigo desconhece a topografia da cidade e confunde M'Pandja com Psak (topônimos designativos de bairros de Bissau, v.33), mas nem por isso desiste de guerrear contra a "república", isto é, contra um país soberano. O verbo da língua guineense utilizado, montia, significa exatamente "caçar". O pau-desangue (po di sangi, v.36) é uma das árvores típicas da região, de madeira muito rija e, sendo difícil de ser cortada, simboliza firmeza. Em língua guineense, o termo matchundadi corresponde a "macheza", no sentido de coragem. Aqui, porém, a idéia de firmeza e coragem reunidas para a defesa da pátria é expressada de forma extremamente irreverente, pois a expressão no firma tchan no matchundadi (v.35 e 36)

15 Tchut é um advérbio de intensidade, mas que nada tem a ver com o sobrenome balanta Na Tchut ou N' Tchut, referido na sétima estrofe, verso 25. 
tem inequivocamente o sentido pornográfico de um vangloriamento do macho (firma mantchundadi literalmente significa "com o pênis erecto"), como homens de verdade. O poeta lança mão de duas metáforas conjugadas, já que o termo po, "pau” (árvore), também é um símbolo fálico. O pau-de-sangue, juntamente com o poilão, são símbolos positivos e importantes da pátria.

Na última estrofe predominam otimismo e orgulho nacional. Huco Monteiro vislumbra um futuro melhor para seu país, ousando sonhar entre bombas e destruição. Os guineenses não desistirão (Certeza na kabeça, Esperança na pitu), lutarão até a vitória final. Resolutos e firmes como o pau de sangue, lá seguirão eles, rumo à vitória, alegorizada na imagem familiar a todo guineense, pois a estrada de Brá, como já foi dito, marcou uma fronteira cruenta entre as tropas adversárias no conflito de 1998/99: djitu ten na glória di Brá. Djitu ten é uma expressão típica da língua guineense, usada mais correntemente na forma negativa: djitu ka ten (não tem jeito, não há solução ou saída), denotando inclusive o espírito conformado e fatalista atribuído à maioria da população, motivo de crítica e censura para aqueles que tentam mudar a situação precária do país. Na euforia da campanha política para as primeiras eleições multipartidárias, acontecidas em 1994, em oposição ao derrotismo pessimista, procurou-se mostrar que o país não estava em situação de calamidade, havia uma saída sim, para o progresso e o desenvolvimento. Djitu ten ${ }^{16}$ aqui é uma exclamação de confiança e pertinácia, afirmação final de crença no futuro da Guiné-Bissau.

A história comum e o passado compartilhado nacionalizaram um pedaço de terra e preencheram o território (nacional) de conteúdo mítico e de sentimentos sagrados (García, ib.). Uma atividade racional, como é o caso da defesa do território, fator, portanto, externo e até certo ponto ocasional, pode favorecer a emergência de uma consciência grupal

\footnotetext{
$16 \mathrm{Ou}$, com mais ênfase ainda, é comum ouvir-se djitu ten ke ten. A expressão foi também usada como título dos Estudos Prospectivos Nacionais a Longo Prazo (National Long Term Perspective Studies), conduzidos pelo Instituto Nacional de Estudos e Pesquisa, o INEP, a partir de 1992. Expressa um voto de confiança no país.
} 
alargada ou a eclosão de um sentimento de dever moral ligado à defesa da pátria (WEBER, 1964). No caso do conflito armado de 98/99, vê-se claramente que a "defesa da barraca" é menos a proteção do território real, que não foi propriamente ameaçado na sua integridade física, do que do território emocional e simbólico, e tal atitude esteve acima do sentimento étnico, priorizando-se apaixonadamente a defesa da soberania e unidade da nação guineense. Para os grupos, o sentimento de honra social compartilhada por todos, além da crença subjetiva comum de constituir uma comunidade, é sumamente importante, daí a lembrança em tantos poemas das lutas libertárias ocorridas no passado, fundadoras da nacionalidade, quando a nação guineense começou a dar seus primeiros passos. A relação que se estabelece entre os vivos e os mortos, entre o passado e o presente é, como já afirmei anteriormente, apoiada em tantos autores, de ordem espiritual e da maior importância, sendo recorrente na literatura guineense.

\section{Motivos do "desassossego da Guiné"}

A novíssima literatura guineense reflete, ao lado desses fortes sentimentos de pertença em relação à nação-território, igualmente o receio da desarmonia entre as etnias e a preocupação face a uma desestabilidade social por motivos de ambição política ou de idéias separatistas que o tribalismo pode acarretar. A ótica de Respício Nuno, o autor de quem passarei a tratar, recai sobre os resultados morais da desordem interna que cumulou com o conflito armado e prosseguiu existindo depois do cessar fogo. Foram priorizados menos o horror ao inimigo do que as razões internas que levaram o país à desgraça e ao descompasso, e o poeta expressa grande desgosto, revolta e até ojeriza pelos atos dos conterrâneos responsáveis pela má governança. 
Em Respício Nuno ${ }^{17}$, como em Huco Monteiro, está bem nítida a presença de uma intenção testemunhal e acusadora, provocada por esse acontecimento limite, extremo, que foi a vivência da guerra. Tratase de uma poesia anti-épica, com seu eixo corrosivo e o efeito desconstrutor da palavra. Recebi do autor, datados de 1999, textos em português e sobretudo na língua guineense, com pesadas críticas cheias de ironia em relação aos políticos e ao governo, ao lado das demonstrações de repúdio pelos horrores vivenciados na guerra. Os títulos revelam logo de saída o estado de espírito do eu poético.

Destaco entre eles o longo poema intitulado "Disgrasa”, com 73 versos em 14 estrofes de extensões desiguais. A tradução literal do título é certamente "desgraça", embora talvez a idéia de calamidade melhor exprima o sentimento do autor. O poeta faz uma crítica aberta e direta a aqueles antigos combatentes da liberdade da pátria, aqui chamados pelo autor de "donos do mato", que subiram na hierarquia e atualmente são donos do poder. São os generais de ontem que hoje ocupam os lugares chave da governança, "golpeando as costas do povo inocente”. O egoismo e a falta de escrúpulo de alguns ocasionaram a desgraça e a miséria que vieram com o descontentamento, a decepção e, como derradeira conseqüência, a guerra, arrasando aldeias e cidades, dividindo e enlouquecendo o povo, lançando a discórdia entre as pessoas, engordando os abutres que se banqueteam com os corpos queimados ou mutilados.

Vejamos o poema na íntegra:

\footnotetext{
17 Respício Nuno Marcelino da Silva nasceu em 1959, em Bissau. Estudou na Rússia, no Instituto Lingüístico de Moscou, concluindo com um mestrado seu curso superior. Até hoje não publicou nenhum livro individual. Está presente com uma dúzia de poemas em crioulo na antologia Kebur (Augel, 1996). Tem também muitos contos na língua guineense, igualmente inéditos. Ocupando diversas vezes a pasta de Secretário Geral da Cultura e dos Desportos, cargo em que se encontra novamente no momento (2005). Agradeço ao autor os esclarecimentos do significado e do contexto cultural de muitas das imagens por ele empregadas.
} 


\section{Disgrasa}

I. 1. Sintadu na baranda di simuladu

2

4

5

6

7

8

9

II. 10

III.

11

12

13

14
Junbulin ku kudadi

Na kil tenpu di fanadu

Ku dunus di matu

Na latchi kalef

Na kosta di pubis nosenti

Kalef di fugu

Kalef di fugu?

Es gora i disgrasa!

Kasadias konkoñi

Kurpus tisna

Utrus padasa

Pubis nbuldja sin paraderu
Desgraça / Calamidade

\section{Sentado na varanda como um esmoler}

a poeira da água (um véu de lágrimas) embaciando os olhos

a razão [misturando-se confusamente] com preocupação

Naquele tempo do fanado

com os donos do mato

Golpeando com a catana (o facão)

nas costas do povo inocente

golpes de fogo

Golpes de fogo?

É o momento da desgraça (Isso agora é uma calamidade!)

[Os moradores d]as casas acorrem para ver os corpos queimados

outros despedaçados (mutilados)

O povo corre sem destino (em pânico) 
IV.

V.

28

29
Moransas padasa

Pabia kañako di kasisas

Mortundadi laga

Disgrasa balia pubis

Tenpu di junta baloba ka ten

Irans panta

Duensa muñungu

Kabesa di jintis

Dudisa ku tisi disgrasa

Disgrasa ku leba fartura

Di jugde

Jugde ku bisia kemansa

Kemansa di banbaran di Guine

Kasisas ku pekaduris

Na torkia dala

Plitikerus bida pasenserus

Sintidu na kabas garandi aldeias destruídas

pela lança das kassissas

a mortandade se espalha

a desgraça divide o povo

Tempo para rituais [e sacrificios] não há

os irans estão chocados

as doenças se alastraram

as pessoas

Endoideceram e isso trouxe a desgraça

a desgraça que levou fartura

para os abutres

abutres que vigiaram os incêndios

O incêndio do berço da Guiné

As kassissas e as pessoas (os mortos e os vivos)

vão trocar as roupas (misturam-se, não se sabe quem é quem)

Politiqueiros viraram intrigantes

a razão está posta na cabaça 
grande

VII.

39

40

41
Kabas garandi ku tisi disgrasa

Disgrasa ki nudadi

Ku barsa Guine

Guine ku as almas na disfindra

Suma manpatas

Ermondadi rapati

Suma Blama ku San Jon

Disgrasa trapaseru

Disgrasa mofinu

Disgrasa futseru

Ku misti gasija na Guine

Disgrasa ku kabesas mandintis

Na sumia

E na sumia son cabaça grande que trouxe a desgraça

Desgraça que é uma má notícia (desgraça da desgraça)

que abraça a Guiné

Guiné onde as almas (os mortos) cairão

como os frutos do mampatas

a fraternidade está [tão] separada

como Bolama [está longe] de São

$$
\text { João }
$$

Desgraça trapaceira

Desgraça mofina

Desgraça feiticeira

que quer hospedar-se na Guiné

Desgraça que as cabeças insanas

estão a semear

e vão semear cada vez mais

VIII.

Disgrasa ntemus

Desgraça teimosa 
a mudança dos tempos

que quis impedir-nos de presenciar

que me dá medo

tenho medo que o mundo

caia no caos

em vez de mudar para o bem

Tenho medo

da areia (das impurezas)

que está no balaio

esperando ser sacudida (jogada 
XI. N'medi

64

XIII. N'medi

68

69

71

72 73

N'medi
Ku kabesa di Guine

Ku korson di Guine

Pa ka disgrasa

Kontinua disgrasia Guine

N'medi ku Guine

Kila son kun medi

E disgrasa di nudadi.
Tenho medo

das cabeças da Guiné (do estado mental)

Tenho medo

do coração da Guiné

Tenho medo

continue a desgraçar a Guiné

Tenho medo pela Guiné

é só disso que tenho medo

dessa desgraça das desgraças.

O poema inicia exprimindo a impotência, identificando na primeira pessoa o esmoler que nada tem, pois tudo perdeu e, envolto na tristeza, relembra o tempo do fanado, isto é, o tempo da preparação para a vida. Para tornarem-se resistentes a toda dificuldade, viviam os iniciandos durante um certo período no mato sagrado e tinham que sofrer certos castigos, como golpes ou pancadas com o kalef (a catana 
ou facão; verso 6). A imagem referente aos "donos do mato", em princípio as divindades, chamadas de irans, confunde-se com a dos antigos combatentes, heróis quase sagrados também e que também viviam sua guerrilha no mato (verso 6). Mas esses, hoje, a catana (o facão) é utilizada para pancadas nas costas do povo inocente /v. 7), que neles confiou, e esses golpes não são para um castigo ou provação construtiva, mas sim trazem a dor, a miséria e a desgraça, são golpes de fogo (v. 9).

A segunda estrofe, com um verso apenas, enfatiza a dramaticidade da situação, a guerra sendo conseqüência da má governança. A terceira estrofe traz a evocação de momentos da guerra (v. 11-15). O povo é atingido pela lança mortífera das kasisas (v. 16), almas penadas portadoras da desgraça, espalhando a morte e o desespero, enquanto o povo está dividido, os indivíduos culpando-se uns aos outros, desirmanados. No verso 18, o autor emprega uma imagem retirada do cotidiano doméstico, dos afazeres femininos, utilizando o verbo balia para expressar a divisão e hostilidade que estão crescendo no seio das etnias; balia é a ação de agitar a peneira para separar a palha do arroz. As mulheres jogam com destreza o cereal para o ar, a parte leve é levada pelo vento, restando os grãos comestiveis.

Até mesmo as divindades se espantam (panta, v. 20), estão chocadas com tudo o que está acontecendo no país. As pessoas, em pânico (sem paradeiro, sem destino), perdem a cabeça, endoidecem (dudisa; v. 22 e 23), não encontram nem mesmo tempo de consultar os oráculos ou os sacerdotes, estado de espírito que está expresso no primeiro verso dessa quarta estrofe (v. 19), com a expressão junta baloba. A baloba é o local sagrado das etnias que praticam a religião tradicional, local aonde se vai para consulta e veneração, para a oferta de oferendas para os sacrifícios rituais. Os abutres, atentos e ávidos, encontram alimentação farta nesse tempo de calamidade (v. 24-27). O banbaran é o pano com o qual as mães cingem o bebê para carregá-lo às costas; banbaran di Guine é um termo freqüentemente empregado na poesia ou em canções, o berço da Guiné (v.27). 
A guerra não só trouxe destruição como perturbou todo o sistema social, a confusão estabeleceu-se, não se sabendo mais por onde passa o limite entre os mortos (as kasisas) e os vivos. Na quinta estrofe, os versos 28 e 29 expressam essa confusão, e o poeta emprega uma imagem de difícil compreensão, uma vez que evoca elementos culturais desconhecidos para nós, leitores exógenos (e não só). As kasisas são os mortos sem sepultura; pekaduris é, na língua guineense, a pitoresca expressão para os humanos de modo geral (independentemente de seus pecados ou falhas). E esses dois grupos, vivos e mortos, confundem (torkia), ou misturam, suas roupas, já não se sabe quem está vivo, quem está morto. Aqui o poeta usa de novo uma parte pelo todo: a dala, é uma peça do vestuário masculino, espécie de cinta ou tanga, usada na luta livre tradicional. Os lutadores, no calor da porfia, confundem e misturam suas tangas, a sinédoque querendo significar que, nesse tempo de conflito e guerra, não se sabe mais quem é quem. Trata-se de um tempo de crise, quando os políticos, depreciativamente designados de politiqueiros e intrigantes (v. 30), só têm o sentido posto na conquista ou na conservação do poder. Nos versos 31 e 32, a cabaça, antes sagrada e portadora de benefícios, tem sua finalidade desviada e traz apenas a desgraça. As muitas anadiploses ou reduplicações nesta estrofe emprestam uma grande densidade ao texto. O termo nudadi, no final dessa estrofe, pode lembrar "novidade", mas de fato significa "má notícia”, sendo praticamente sinônimo de disgrasa.

Todo guineense conhece a comparação contida nos versos 35 e 36: as almas caem mortas como os frutos do mampatas, que é uma árvore frutífera cujos frutos caem dos galhos tanto quando verdes como quando maduros, portanto aqui a morte ceifa indiscriminadamente tanto jovens como velhos. O último verso dessa estrofe refere-se a duas localidades: a ilha de Bolama e o ponto de onde partem os barcos para lá, São João (v.38). Os guineenses estão tão desunidos, tão separados quanto as duas localidades estão distantes uma da outra. Não se trata de uma desunião 
entre as etnias e sim entre os aproveitadores e oportunistas de um lado, e do outro o povo, impotente contra tantos desmandos.

As duas estrofes seguintes trazem mais uma vez imagens locais: em anáforas eloqüentes, o poeta impropera contra o tormento (a disgrasa) que assola o país (v. 40-42) e contra aqueles que, teimando em querer preservar os antigos privilégios, não sabem ou não querem reconhecer a "mudança dos tempos" (v. 48), impedindo, com sua ambição, o povo de viver na simplicidade do cotidiano: o camponês com suas colheitas de caju ou os pescadores (aqui designados por um povo pescador, os Nhominkas) com suas pescarias (v. 49-52). Os permanentes conflitos provocam a mortandade e não é possivel "levantar a esteira do chão", guardar a esteira onde as mulheres se sentam durante o velório para carpir seus mortos, pois precisa-se dela todo o tempo (v. 53-54).

As últimas estrofes, muito curtas e repetitivas, insistem sobre o sentimento de medo e preocupação provocado pela atual situação do país. A enunciação performativa, utilizando sete vezes a forma verbal na primeira pessoa (insistentemente expressada pelo pronome pessoal n', que significa eu), retoma o sujeito poético da primeira estrofe, emprestando um cunho confessional cuja dramaticidade é reforçada pelas anáforas.

Profundamente políticos, esses poemas que estamos analisando não negligenciam o valor estético. Da linguagem poética com suas metáforas não se espera, entretanto, aqui, uma função meramente decorativa. O texto, fazendo sobressair símbolos pertencentes a espaços múltiplos de participação, recusa uma crítica direta ou argumentativa, procurando antes, pela linguagem metafórica, através do inesperado e do incomum de suas imagens, surpreender o leitor que passa assim por um processo de reflexão e de descoberta, desempenhando uma função de tomada de conhecimento e de reconhecimento.

"Ermondadi”, outro poema inédito de Respício Nuno, escrito em agosto de 1999, cerca de dois meses após o término da guerra, difere do anterior menos pela sua motivação do que pela sua abordagem e desenvolvimento temático. O antigo presidente (João Bernardo "Nino" 
Vieira) tinha sido deposto e um novo período começava, tributário das esperanças de mudança e o desejo de paz da população. Entretanto, após a retirada das tropas estrangeiras, a verdadeira paz só poderia ser alcançada com a reconciliação fraterna entre os compatriotas, envoltos ainda em discórdias e desunião, sendo imprescindível que os políticos voltassem à razão e se ocupassem do bem estar do povo e a governança fosse pautada pela "aliança", pelo "casamento" "da fraternidade da terra com seus filhos”. O poeta evoca as crenças coletivas e as tradições populares, apelando para os sacrificios rituais para livrar o povo das calamidades, aqui metaforizadas na figura do urdumunhu, redemoinho ou vendaval, que se abateu sobre a Guiné. É um poema de quarenta e nove versos distribuídos em seis estrofes:

\section{Ermondadi}

I.1 Urdumuñu peteli

2

3

4

5

6

7

I.I 8
Batenti di Guine

Kabas di sorti pirsisadu

Pa limpsa paraderu des urdumuñu

Ku na rapasa

Ermondadi di tera

Ku si fijus

Difuntus tisi klarensa

Ku pukentan korson

\section{Fraternidade}

Um tubmilhão escancarou (abriu com violência)

As portas da Guiné

é preciso uma cabaça da sorte

para explicar (decifrar) a origem (a razão) desse turbilhão

que baralhou tudo [perturbando]

a fraternidade da terra

e de seus filhos. 
10

11

III. 1

2

13

14

15

16

17

18

19

IV.

20

21

22

23

24

25
I pirsis sirmonia

Di Guine ku si fijus

Simonia

nunde ku sangui

ka na darmadu

binu ka na bibidu

son yagu friu di puti

ku na dosadu

ku blungujuba kinti

pa madri pudi limpsa

Kubanba na firbintidu

sin siti son ku liti

baju na bajadu

$\sin$ sajô

sin bumbulum

nin tambur é preciso [fazer-se] uma cerimônia

Da Guiné com seus filhos.

Cerimônia

Em que o sangue

não será derramado

não se tomará vinho

somente água fresca do pote

que será adoçada

com o chá de blungujuba quente

para purificar nosso ventre (nossos corações).

A kubamba será preparada

sem óleo de palma, somente com leite

vamos dançar uma dança

sem sajô (sem guizos nas pernas)

sem o bater do bumbulum

nem do tambor 
26

27

28

9

30

V.

31

32

33

34

35

36

37

38

VI.

39

40 nin kabas garandi

pa banu di ermondadi

entra na sintidu mokus

pa pudi mara ermondadi

di tera ku si fijus

Omis ku minjeris

na baja ku rabada na mon

ondadi pudi sikidu

dias, dias ki na bajadu

Suma na fanadu

ma sin tchor-mama

nin kalef

pa pudi firmanta ermondadi

É simonia

Na ermons também sem a cabaça grande [de oferendas]

para que a proclamação da fraternidade

penetre nos ouvidos surdos (nas cabeças ocas)

para fazer a aliança da fraternidade

Da terra com seus filhos.

Homens e mulheres

vão dançar com a cintura na mão (desnudos)

para a fraternidade poder firmar-se

vamos dançar durante dias e dias

Tal como no fanado

mas sem gritos do kankuran

nem golpes de catana (nem castigo)

para poder firmar (selar) a fraternidade.

Essa cerimônia

entre irmãos 
$\mathrm{Ku}$ si fijus na ermondadi vai de casa para o cemitério

para as kassissas se acalmarem

para o chão tornar-se doce

para a lagoa de sangue secar

sem gritos do kankuran

nem golpes de catana

para a terra de uma vez por todas

poder contrair casamento

com seus filhos, na fraternidade.

Em "Ermondadi", o sujeito poético compara a guerra a um grande vendaval que provoca redemoinhos e espalha a destruição, "escancarando as portas da Guiné" (v.1-2), expondo o país a todos os perigos. Quando uma infelicidade ou uma enfermidade cai sobre uma família, os costumes tradicionais levam os indivíduos a procurarem uma explicação através da consulta aos oráculos ou curandeiros. Para se descobrir a razão da infelicidade fazem-se cerimônias, isto é, de rituais de purificação, de sacrifício, de cura ou de adivinhação. Nessas ocasiões, em muitas etnias há a oferenda sacrificial de um animal, com derramamento de sangue, além do usos da aguardente ou do vinho (de palma ou de caju) e da obrigatoriedade de danças rituais. A cabaça (kabas) é usada em toda a região como recipiente, utensílio doméstico de várias serventias, objeto em que se recolhem, guardam ou transportam alimentos ou líquidos, servindo também de prato para as refeições em comum. A cabaça é igualmente indispensável nas cerimônias religiosas. É o receptáculo de oferendas, da água ritual, enfim, é carregada de 
simbologia ligada ao sagrado. O autor emprega na primeira estrofe a expressão kabas di sorti, referindo-se à cabaça ritual (v.3).

Na segunda estrofe, Respício Nuno faz referência aos mortos (difuntus; v. 8), os antepassados, ligados indissociavelmente aos vivos nas culturas tradicionais africanas e que tudo sabem, sendo capazes de explicar o que estava acontecendo. Para isso, porém urge uma cerimônia e o poeta quer que desta vez essa cerimônia ritual seja diferente e sem obedecer as regras rituais tradicionais. O poeta se permite na terceira estrofe ousadas transgressões, desconstruindo os ritos e sinalizando com isso o quanto é especial a situação calamitosa em que o país se encontrava: aqui, nesta festa singular, não correrá sangue (v.13-14), nem se beberá nenhuma bebida alcoólica (v.15). Será preciso tomar-se o chá tradicional receitado para as recém-paridas, infusão feita com a erva blungudjba (ou bulungudjuba), destinada a limpar, desinfetar o ventre depois do parto, própria portanto também para purificar os corações empedernidos (v.18-19).

$\mathrm{Na}$ quarta estrofe o autor expressa a esperança e o desejo de paz entre seus conterrâneos, sonhando com uma aliança entre todos os guineenses. Os símbolos e as marcas étnicas presentes no poema não se confinam a uma só etnia, muito pelo contrário, a intenção do autor é justamente celebrar a união entre os diferentes grupos do país, sem preferência de uma raiz fundadora, mas risomaticamente múltipla, como sugerem Deleuz e Guattari (1980).

Em todo casamento há naturalmente banquetes e danças. Nos casamentos muçulmanos, na etnia mandinga, a iguaria ritual, destinada à noiva, indispensável numa festa de bodas, é a kubanba (v.20), preparada com azeite de dendê (óleo de palma), leite coalhado e arroz cozido bem mole. O prato, também apreciado em outras ocasiões, é comumente chamado de siti ku liti. Mas, para esse momento excepcional, a kubanba será servida sem o azeite vermelho da palmeira do dendê, contrariando todas as regras (v.21). Somente o leite, branco, será usado. A imagem quer expressar o desejo de uma festa de paz, sem derramamento de sangue. Também sem qualquer tipo de música, uma 
dança silenciosa, portanto, para que a mensagem de paz possa penetrar nos ouvidos surdos, sem o acompanhamento dos instrumentos característicos que são o bumbulum, o sajô, o tambor (isto é, sem o troar dos canhões ou fuzis; v.22-25) e onde homens e mulheres dançarão nus (a "rabada" na mão; v.31-32), desarmados e de coração puro, na intimidade e confiança de irmãos. Na alegria da confraternização, a festa durará muitos dias, tal como acontece no final do tempo do fanado, a importante fase da iniciação, quando se festeja o fim da difícil e longa reclusão e a entrada para a vida adulta (v.35).

Muitas imagens originais povoam a quinta estrofe. $O$ sujeito poético deseja essa grande festa sem ameaça de nenhum perigo. Sem o tchor-mama nin kalef (v.36-37), isto é, sem os gritos que acompanham a presença da divindade do kankuran e também sem castigo, sem os golpes dados com o lado cego da catana ou facão (v.37), gesto também próprio das festividades que acompanham o final do fanado. O kankuran, com sua aparência medonha, inspira pavor mas também tem a faculdade de proteger os iniciados. Quando ele sai à rua, em geral por causa de algum acontecimento negativo, o povo o acompanha com gritos (tchormama) e encenações de balbúrdia.

As alusões a costumes e rituais tradicionais transmitem aos familiarizados com esse ambiente cultural uma aura de confiança, de confidência, uma visão endógena. O leitor e a leitora guineenses vão reconhecer o contexto no qual esse festim excepcional e esdrúxulo deve acontecer e ao mesmo tempo vão evocar sua própria experiência, vivida diretamente no fanado ou como espectadores, no âmbito da vivência comunitária das festividades de encerramento desse período. As enunciações desse poema adquirem um sentido especial para os "de dentro", difícil de serem apreendidas pelo leitor exógeno. Há então uma carga de subjetividade que leva a um novo enquadramento daquilo que está latente na experiência individual ou coletiva, fazendo aflorar ao espírito ou à memória uma lembrança, uma evocação que as inesperadas metáforas catapultam para uma nova perspectiva. As 
antigas significações adquirem um novo revestimento, uma outra dimensão subjetiva. Ao desconstruir as cerimônias rituais, Respício Nuno lança conscientemente mão da ruptura de certas seqüências conhecidas e familiares, retira propositalmente um dos elos de uma certa cadeia tradicional (por exemplo, modificando os preparativos do festim nupcial, excluindo a obrigatória música) e esse procedimento insólito e ousado vai provocar o efeito surpresa e opera uma ressignificação, efeito esse justamente calculado. Essa substituição metafórica e não real vai ocupar o lugar do elo suprimido na seqüência tradicional, possibilitando uma coexistência das duas cadeias (a real e a metafórica) que se justapõem e se interpenetram, possibilitando que a mensagem do poeta atinja o impacto desejado e vá engendrar um novo universo de referências.

\section{A representação da nação}

Huco Monteiro e Respício Nuno são porta-vozes de um estado de espírito pessimista e de preocupação bastante generalizado no país na presente conjuntura. A subjetiva tomada de consciência por parte dos poetas de aspectos da especificidade étnica e cultural dos diferentes grupos contituintes da nação guineense é importante como apropriação simbólica da nação e com isso como afirmação identitária justamente num momento de profunda crise. Os poetas buscam o entendimento entre as etnias que convivem no país e o conseguem pela apreensão simbólica do "locus" individual como espaço da coletividade que forma o "nós" constituidor da nação guineense.

Foi possivel, nesses poemas, constatar a interrelação entre a textualidade e o complexo conjunto de códigos culturais que muitas vezes nos escapam e exigem do receptor exógeno um esforço consciente de decodificação. Ao estudar-se a nova literatura guineense, é essencial compreender o ato criativo tanto pelo seu valor estético quanto como reverberação do substrato cultural ali implíscito. O texto literário se engendra num encadeamento de múltiplas significações e seu sentido 
mais profundo advém da sua dimensão simbólica. Traçando uma ligação entre os significantes e seus significados, buscando a revelação da significação engastada nesses versos excepcionais (e espero que minha busca sirva a outros leitores e desperte novas leituras), procurei deslindar a complexa configuração simbólica de alguns aspectos dessa mundivivência para nós tão pouco familiar.

Huco Monteiro e Respício Nuno são porta-vozes de um estado de espírito bastante generalizado no país na presente conjuntura. A harmonia é turvada em tempo de crise e essa crise já vem durando alguns $\operatorname{anos}^{18}$. A Guiné-Bissau continua sendo um espaço periférico em relação tanto à África como e sobretudo à Europa, com consideráveis deficiências estruturais em questões de educação, de saúde, de transporte, ausência de indústrias, de infra-estruturas em geral, de práticas de democracia e de responsabilidade política e administrativa. $\mathrm{E}$, embora se possa falar que persiste no país a situação de uma coexistência praticamente desprovida de conflitos graves em um espaço guineense, predominando um sentimento de nação-estado que transcende as diferenças étnicas locais e regionais, as pressões de natureza econômica e mesmo manipulações político-partidárias têm levado, nos meios urbanos, presentemente, a uma certa tensão entre as etnias, a uma "etnização" (por parte sobretudo de alguns políticos) da procura de solução para os problemas sociais. A isso o poeta chama de "disgrasa” ou calamidade, "praga”, "disasosegu”, "nudadi”, empregando, com a arma do seu discurso poético, os mais diversos meios para esconjurar as dificuldades que atrasam e emperram o desenvolvimento e a estabilidade social.

\footnotetext{
18 A inquietude tem aumentado sobretudo desde 6 de outubro de 2004, quando o chefe do Estado Maior do exército foi barbaramente assassinado e quase se deu mais um golpe de estado. Esse foi mais um dos muitos assassinatos políticos que sempre pautaram a luta pelo poder no país. As eleições de junho e julho de 2005 provocaram uma grande tensão entre os políticos e no seio do povo. Por isso mesmo, a palavra de ordem dos últimos anos tem sido a da reconciliação nacional, muitos defendendo a necessidade de uma anistia geral dos erros e crimes passados para se tentar recomeçar do zero uma nova era política e social.
} 
A subjetiva tomada de consciência por parte dos poetas de aspectos da especificidade étnica e cultural dos diferentes grupos contituintes da nação guineense é importante como apropriação simbólica da nação e com isso como afirmação identitária. Viu-se que o entendimento entre as etnias que convivem no país é conseguida pela apreensão simbólica do locus individual como espaço da coletividade que forma o "nós" constituidor da nação guineense. Verificou-se um processo de apropriação do espaço vital, no plano da emoção e do símbolo, ao se emprestarem significações a elementos desse espaço vital, dessa "barraca" reterritorializada.

Ao estudar-se a nova literatura guineense, é imperativo captar-se nela uma textualidade mais além, uma textualidade não manifesta claramente mas que, ao ser analisada, desnuda sentidos e aspectos culturais subjacentes da maior importância. O ato criativo, ao ser encarado tanto pelo seu valor estético quanto como revelação do substrato cultural, plasmador não somente de atitudes mentais individuais como da essência coletiva de um povo, constitui um dos fundamentos de onde emerge a identidade de uma comunidade, ou mesmo da nação interna, imaginada e desejada. O texto literário se engendra numa semiose, num concatenar de significações, e seu sentido mais profundo advém da sua dimensão simbólica. Traçando uma ligação entre os significantes e seus significados, buscando a revelação da significação engastada nesses versos excepcionais (e espero que minha busca sirva a outros leitores e desperte novas leituras), procurei deslindar a complexa configuração de diferentes aspectos dessa mundivivência para nós tão pouco familiar, enredada nos interstícios da intertextualidade.

Bibliografia

Anderson, Benedict (1989): Nação e Consciência Nacional. São Paulo: Ática. 
Appiah, Kwame Anthony (1997): Na casa de meu pai. Rio de Janeiro: Contraponto.

Augel, Moema Parente (Coordenação e prefácio) (1996): Kebur. Barkafon di poesia na kriol, Bissau: Instituto Nacional de Estudos e Pesquisa (INEP).

Augel, Moema Parente (1998a): A nova literatura da Guiné-Bissau, Bissau: Instituto Nacional de Estudos e Pesquisa (INEP).

Augel, Moema Parente (1998b): Guiné-Bissau ka pudi kaba. Na internet: hppt:/www.uni-bielefeld.de/sdrc/homesdrc .

Augel, Moema Parente, "Disasusegu di Guiné. Der militärische Konflikt von 1998/99 in der Literatur Guinea-Bissaus", in: Tranvía. Revue der iberischen Halbinsel, $\mathrm{n}^{\circ} 62$ (set. 2001), p. 11-13.

Augel, Moema Parente, "Regimekritik am Beispiel der guineischen Literatur", in: afrika spectrum. Zeitschrift für gegenwartsbezogene Afrikaforschung. Hamburg: Institut für Afrikakunde Hamburg, ano 35, 2000/1, p.65-80. Nova impressão in: Augel, Johannes / Meyns, Peter (Org.) (2001): Transformationsprobleme im portugiesischsprachigen Afrika, Hamburg: Institut für Afrika-Kunde, p. 249-266.

Augel, Moema Parente, "Canto-poema do desassossego". Posfácio in: Odete Semedo (2003): No fundo do canto. Viana do Castelo: Câmara Municipal, p.185-195.

Aurigemma, Pascoal D'Artagnan (1996): Djarama e outros poemas, Bissau: Instituto Nacional de Estudos e Pesquisa (INEP). Org., Nota editorial e Notas de M. P. Augel

Barth, Fredrik, "Grupos étnicos e suas fronteiras", in: Poutignat, Philippe / Streiff-Fenart, Jocelyne (1998): Teorias da Etnicidade. Seguido de Grupos étnicos e suas fronteiras de Fredrik Barth. São Paulo: Editora da UNESP, p.185-227.

Bhabha, Homi K. (1998): O local da cultura. $4^{\text {a }}$ ed. Belo Horizonte: Editora UFMG.

Dalcastagnè, Regina (1996): O espaço da dor. O regime de 64 no romance brasileiro. Brasília: Universidade de Brasília.

Deleuze, Gilles / Guattari (1980):, Félix, Mille plateaux, Paris: Minuit.

Geertz, Clifford (2001): O saber local. 4ª ed.. Petrópolis: Editora Vozes. 2001.

Hall, Stuart (2000): A identidade cultural na pós-modernidade. $4^{\mathrm{a}}$ ed . Rio de Janeiro: DP\&A.

Mai, Ulrich, "Symbolische Aneignung und Ethnizität", in: Masuren: Ein interdisziplinäres Forschungskonzept. Bielefeld: Universität Bielefeld, Fakultät für Soziologie, 1995.

Mendy, Peter Karibe (1994): O colonialismo português em África: a tradição da resistência na Guiné-Bissau, 1879-1959. Lisboa: Imprensa Nacional-Casa da Moeda / Bissau: INEP.

Pélissier, René, Naissance de la Guiné. Portugais et Africains en Sénégambie (1841-1936). Orgeval: Pélissier.

Poutignat, Philippe e Jocelyne Streiff-Fenart (1998): Teorias da Etnicidade. Seguido de Grupos étnicos e suas fronteiras de Fredrik Barth. São Paulo: Editora da UNESP.

Scantamburlo, Luigi (2002) Dicionário Guineense-Português. Disionariu guinensi-portuguis. Lisboa: Edições FASPEBI (Vol. II).

SORONDA. Revista de Estudos Guineenses. Bissau: Instituto Nacional de Estudos e Pesquisa (INEP), Nova Série, $\mathrm{n}^{\circ} 2$, dezembro 2000.

Tcheka, Tony (António Soares Lopes Jr.) (1996): Noites de insónia na terra adormecida, Bissau: Instituto Nacional de Estudos e Pesquisa (INEP). Prefácio de M. P. Augel. 
Weber, Max (1964): Wirtschaft und Gesellschaft. Grundriß der verstehenden Soziologie. Colônia/Berlin: Kiepenheuer \& Witsch. 